\title{
FAO SSF Guidelines: Pedoman Sukarela untuk Menjamin Keberlanjutan Perikanan Skala Kecil di Indonesia
}

\author{
Belvi Vatria \\ Jurusan Ilmu Kelautan dan Perikanan, Politeknik Negeri Pontianak \\ Jalan Ahmad Yani, Pontianak Tenggara, Pontianak, Indonesia 78124 \\ Email: belvi189@gmail.com
}

\begin{abstract}
The sustainable development goals of 2030 (SDGs) encourage small-scale fisheries to contribute more to SDGs one and two goals, namely no poverty and zero hunger. In 2014 the FAO has released voluntary guidelines to ensure sustainable small-scale fisheries in the context of food security and poverty alleviation (FAO SSF Guidelines) which are a reference worldwide. The purpose of this study is to examine the progress of implementing the FAO SSF Guidelines in Indonesia. This research is a qualitative research through the Literature Review approach. The results of this study found that small-scale fisheries played a very important role in poverty alleviation and world tenure security, especially Indonesia. At the policy level, responsible fisheries management (CCRF) which is the main reference for sustainable fisheries development has been accommodated in Indonesian law, especially in Law Number 45 of 2009. Indonesia has also implemented the FAO SSF Guidelines in national law, especially in Law Number 7 of 2016 concerning Empowerment and Protection of Fishermen, Fish Farmers and Salt Farmers. However, it is necessary to improve small-scale fisheries governance starting from institutional synergy between the central, provincial and district / city governments and synchronization of laws and implementing regulations under both central and regional levels, as well as the participation of fishing communities in them.
\end{abstract}

Key words: CCRF, food security, management, poverty, sustainability

Abstrak: Tujuan pembangunan berkelanjutan 2030 (SDGs) mendorong perikanan skala kecil untuk berkontribusi lebih besar pada tujuan SDGs kesatu dan kedua yaitu tanpa kemiskinan (no poverty) dan tidak ada kelaparan (zero hunger). Tahun 2014 FAO telah merilis pedoman sukarela untuk menjamin perikanan skala kecil yang berkelanjutan dalam konteks ketahanan pangan dan pengentasan kemiskinan (FAO SSF Guidelines) yang menjadi acuan di seluruh dunia.Tujuan penelitian ini adalah untuk mengkaji perkembangan implementasi FAO SSF Guidelines di Indonesia. Penelitian ini merupakan penelitian kualitatif melalui pendekatan Literature Review. Hasil penelitian ini menemukan bahwa perikanan skala kecil sangat berperan penting terhadap pengentasan kemiskinan dan ketahanan pengan dunia khususnya Indonesia. Dalam tataran kebijakan, tata laksana perikanan yang bertanggung Jawab (CCRF) yang merupakan acuan utama pembangunan perikanan berkelanjutan telah diakomodir dalam hukum Indonesia terutama pada Undang-Undang Nomor 45 Tahun 2009. Indonesia juga telah mengimplementasikan FAO SSF Guidelines dalam hukum nasional terutama pada UndangUndang Nomor 7 Tahun 2016 tentang Pemberdayaan dan Perlindungan Nelayan, Pembudi Daya Ikan, dan Petambak Garam. Namun demikian diperlukan penyempurnaan tata kelola perikanan skala kecil mulai dari sinergitas kelembagaan antara pemerintah pusat, provinsi, dan kabupaten/kota dan singkronisasi Undang-Undang dan peraturan pelaksana di bawahnya baik tingkat pusat maupun daerah, serta partisipasi masyarakat nelayan didalamnya.

Kata kunci: CCRF, keberlanjutan, kemiskinan, ketahanan pangan, pengelolaan

Dalam tujuan pembangunan berkelanjutan 2030 (SDGs) sektor perikanan menempati posisi strategis yang berada pada tujuan empat belas yaitu kehidupan di bawah 
laut (life below water). Sementara itu, perhatian khusus kepada perikanan tangkap skala kecil atau biasa dikenal dengan sebutan perikanan skala kecil berada pada tujuan 14.b yaitu meminta setiap negara menyediakan dan melindungi hak akses untuk perikanan skala kecil (COFI 2016).

Hal ini secara simultan dapat mendorong perikanan skala kecil untuk berkontribusi lebih besar pada tujuan kesatu yaitu tanpa kemiskinan (no poverty) dan tujuan kedua yaitu tidak ada kelaparan (zero hunger)(FAO 2018b). Lebih dari $90 \%$ kegiatan perikanan tangkap di Indonesia didominasi oleh perikanan skala kecil (BPS 2019b). Namun demikian, UndangUndang Nomor 7 Tahun 2016 telah merevisi kategori perikanan tangkap skala kecil menurut Undang-Undang Nomor 45 Tahun 2009 tentang Perikanan, yang membatasi ukuran kapal nelayan skala kecil <5 GT, ditingkatkan menjadi <10 GT. Hal ini tentu saja semakin memperluas dominasi perikanan skala kecil di Indonesia, sedangkan sumberdaya ikan (SDI) semakin terbatas.

Sementara itu, menurut Undang-Undang Nomor 45 Tahun 2009 tentang Perikanan, nelayan skala kecil ini tidak diatur atau dibatasi untuk menangkap ikan di perairan Indonesia mana pun dan dibebaskan dari berbagai izin dan pajak, mereka hanya diminta untuk melaporkan keberadaan mereka kepada otoritas kompeten setempat. Nelayan kecil yang menjadi mayoritas pada sektor perikanan tangkap di Indonesia, jika tanpa pengaturan (unregulated) pada gilirannya akan menimbulkan banyak masalah baru. Dengan demikian, isu dan permasalahan pembangunan perikanan skala kecil di Indonesia saat ini menjadi semakin kompleks.

Tantangan utama dalam pembangunan perikanan skala kecil adalah meningkatkan kesejahteraan nelayan kecil. Selama nelayan kecil masih dalam keadaan miskin relatif sulit untuk diajak berbicara tentang pembangunan jangka panjang (Vatria et al. 2019b). Oleh karena itu, kondisi kehidupan mereka harus dipulihkan terlebih dahulu. Di sisi lain, nelayan miskin tidak dapat memulihkan diri mereka sendiri untuk keluar dari kemiskinan, karena mereka sendiri sedang dalam kondisi yang tidak berdaya.

Nelayan skala kecil saat ini secara ekonomi kurang diperhatikan dan sering termarjinalkan (Schuhbauer dan Sumaila 2016). Pada beberapa lokasi di Indonesia jumlah nelayan miskin terus meningkat. Garis kemiskinan di Indonesia pada bulan Maret 2019 tercatat Rp425.420/kapita/bulan (BPS 2019a). Dengan asumsi satu rumah tangga nelayan memiliki 3 sampai 4 orang anak maka pengeluaran mereka berkisar Rp2.127.100 sampai Rp 2.552.520. Rumah tangga nelayan di Indonesia diperkirakan berkontribusi sekitar $20 \%$ dari total penduduk miskin secara nasional, dimana dalam sepuluh tahun terakhir profesi nelayan terus menurun secara drastis.

Minimnya penghasilan yang didapat dan besarnya risiko saat melaut diduga membuat nelayan lebih memilih profesi lainnya yang memberikan penghasilan lebih baik. Masalah kemiskinan nelayan kecil semakin diperparah oleh over fishing, penurunan produktivitas perikanan, dan konflik. Terdapat tiga kelompok nelayan miskin yang dapat diidentifikasi yaitu: sebagian besar buruh kapal ikan, pemilik perahu skala kecil, dan pedagang kecil hasil tangkapan ikan.

Aktor utama dalam pengelolaan perikanan skala kecil adalah: nelayan, pedagang, pejabat pemerintah, dan organisasi swadaya masyarakat (LSM). Menurut (Vatria et al. 2019b) nelayan skala kecil sangat kritis dalam mempertahankan sumber pendapatan, peluang pengembangan mata pencahariannya, namun karena keterbatasannya mereka 
mengalami kesulitan dalam pemanfaatan sumber daya ikan (SDI) tersebut. Sehingga banyak nelayan kecil terkunci dalam kemiskinan dan ketidakpastian mata pencaharian mereka.

Kemiskinan nelayan yang terus meningkat saat ini merupakan kegagalan pembangunan perikanan konvensional dimasa lalu. Penyebab utama kegagalan pembangunan perikanan skala kecil dimasa lalu diduga terletak pada kurangnya koherensi antara tujuan pembangunan dan pendekatan yang dipilih (Garcia et al. 2018; Vatria et al. 2019b). Kegagalan dalam pembangunan bersifat multiplier effect dimana komunitas nelayan bukan satu-satunya kelompok orang yang terkena dampak kegagalan pembangunan, hal tersebut dapat menyebar ke seluruh rantai nilai dan komunitas pesisir terluas yang mungkin juga menderita akibat kegagalan pembangunan tersebut (Vatria 2019)

Perikanan skala kecil dan artisanal, meliputi seluruh kegiatan-kegiatan dari mata rantai pra-panen, panen dan setelah panen yang dilakukan oleh laki-laki dan perempuan, berperan penting dalam ketahanan pangan dan gizi, pengentasan kemiskinan, pemerataan pembangunan dan pemanfaatan sumber daya yang berkelanjutan. Perikanan skala kecil menjadi sumber pangan yang bergizi untuk pasar lokal, nasional dan internasional serta menghasilkan pendapatan dalam mendukung perekonomian lokal dan nasional. Perikanan skala kecil saat ini memainkan peran penting sebagai sumber mata pencaharian, ketahanan pangan, dan pendapatan bagi jutaan orang di seluruh dunia baik di negara maju maupun negara berkembang (FAO 2015). Selain itu, perikanan skala kecil saat ini sangat berkontribusi untuk memelihara pekerjaan masyarakat pesisir, mempertahankan struktur sosial, dan kesehatan ekonomi masyarakat kecil (Veiga et al. 2016).
Mengingat peran penting perikanan skala kecil dalam mendukung keberhasilan pembangunan berkelanjutan 2030 (SDGs) dan kondisinya yang sangat memprihatinkan, maka FAO pada tahun 2014 telah merilis pedoman sukarela untuk menjamin perikanan skala kecil yang berkelanjutan dalam konteks ketahanan pangan dan pengentasan kemiskinan (FAO SSF Guidelines). Pedoman ini menjadi acuan dan himbauan bagi seluruh negara di dunia terutama negara berkembang termasuk Indonesia untuk menjamin keberlanjutan perikanan skala kecil. Oleh karena itu tujuan penelitian ini adalah untuk mengkaji berkembangan implementasi FAO SSF Guidelines di Indonesia.

\section{METODE}

Penelitian` ini merupakan penelitian kualitatif melalui pendekatan Literature Review atau tinjauan pustaka. Studi literature review merupakan cara yang dipakai untuk mengumpulkan data atau sumber yang berhubungan pada sebuah topik tertentu yang bisa didapat dari berbagai sumber seperti jurnal, buku, internet, dan pustaka lain (Sugiyono 2013).

Setelah melakukan literature review, selanjutnya peneliti membuat rangkuman menganalisis dan melakukan sintesis secara kritis dan mendalam dari paper-paper yang direview atau ditinjau. Hasil dari rangkuman, analisis dan sintesis ini kemudian dituliskan secara deskriptif dalam bentuk artikel ilmiah.

Pendekatan deskriptif digunakan untuk menggambarkan, mengeksplorasi, dan mengklarifikasi semua masalah dan fenomena penelitian yang diuji dengan interprestasi yang tepat. Fenomena itu dapat berupa bentuk, aktivitas, perubahan, karakteristik, hubungan, kesamaan, dan perbedaan antara fenomena yang satu dengan fenomena lainnya.

Kajian penelitian ini adalah untuk menguraikan perkembangan implementasi 
pedoman sukarela menjamin perikanan skala kecil yang berkelanjutan dalam konteks ketahanan pangan dan pengentasan kemiskinan di Indonesia. Pedoman sukarela ini merupakan terjemahan dari Voluntary Guidelines for Securing Sustainable Small-scale Fisheries in the Context of Food Security and Poverty Eradication (FAO SSF Guidelines) yang telah disahkan pada Sidang FAO Council ke-149 bulan Juni tahun 2014. FAO SSF Guidelines ini merupakan pelengkap dari tata laksana untuk perikanan yang bertanggung jawab (CCRF) yang diterbitkan FAO pada tahun 1995.

Untuk menguraikan perkembangan implementasi FAO SSF Guidelines tersebut di Indonesia maka studi Literature Review difokuskan pada pokok kajian tentang: peran penting perikanan skala kecil, tata laksana perikanan yang bertanggung jawab (CCRF), dan pedoman sukarela menjamin perikanan skala kecil yang berkelanjutan (FAO SSF Guidelines).

\section{HASIL DAN PEMBAHASAN}

Peran Penting Perikanan Skala Kecil. Peran penting perikanan skala kecil untuk kesejahteraan manusia dan pembangunan berkelanjutan semakin diakui karena kontribusinya terhadap ketahanan pangan dan asupan gizi masyarakat serta terhadap peluang yang mereka wakili untuk pengentasan kemiskinan (COFI 2016; Westlund dan Zelasney 2019).

Dalam konteks pengentasan kemiskinan, saat ini lebih dari 60 juta orang di negara-negara berkembang bergantung pada perikanan sebagai sumber mata pencahariannya (Nguyen et al. 2016). Sektor perikanan skala kecil telah menyediakan lapangan kerja langsung bagi lebih dari 39 juta nelayan di seluruh dunia (Kalikoski dan Franz 2014). Mereka mempekerjakan $87 \%$ dari populasi orang dewasa, menghasilkan rata-rata $82 \%$ dari semua pendapatan rumah tangga (BarnesMauthe et al. 2013).

Di sisi lain, saat ini diperkirakan sebesar 736 juta orang hidup di bawah garis kemiskinan internasional pada tahun 2015 (World Bank 2018). Sementara itu, di Indonesia pada tahun 2018 jumlah penduduk miskin mencapai 25.95 juta orang atau sebesar $9.82 \%$ dari total jumlah penduduk (BPS 2019a). Rumah tangga nelayan di Indonesia diperkirakan berkontribusi sekitar $20 \%$ dari total penduduk miskin secara nasional, dimana dalam sepuluh tahun terakhir profesi nelayan terus menurun secara drastis. Minimnya penghasilan yang didapat dan besarnya risiko saat melaut diduga membuat nelayan lebih memilih profesi lainnya yang memberikan penghasilan lebih baik.

Terkait dengan ketahanan pangan FAO (2018a) menyatakan bahwa pada tahun 2016 sekitar $88 \%$ atau lebih dari 151 juta ton, dari total produksi perikanan digunakan untuk konsumsi manusia langsung. Sisanya sebanyak $12 \%$ atau sekitar 20 juta ton diperuntukkan bagi produk non-pangan, terutama untuk pembuatan tepung ikan dan minyak ikan. Sekitar $45 \%$ ikan untuk konsumsi manusia adalah dalam bentuk hidup dan segar.

Sementara itu, pada tahun 2013 konsumsi ikan dunia per kapita diperkirakan $19.8 \mathrm{~kg}$, dengan ikan menyumbang sekitar $17 \%$ dari populasi yang mengonsumsi protein hewani dan $6.7 \%$ dari semua protein yang dikonsumsi. Secara global, ikan dikonsumsi oleh sekitar 4.5 miliar orang dengan hampir $20 \%$ dari rata-rata asupan protein hewani per kapita mereka. Perkiraan awal untuk tahun 2016 menunjukkan pertumbuhan lebih lanjut dalam konsumsi per kapita menjadi sekitar $20.3 \mathrm{~kg}$ (FAO 2018a). Sementara itu, konsumsi ikan di Indonesia pada tahun 2014 mencapai 37.89 kg/kapita (KKP 2015). Data statistik perikanan FAO mencatat produksi perikanan dunia terus tumbuh dan mencapai 170.9 juta ton pada tahun 2016 (FAO 
2018a). Dari total ini produksi penangkapan ikan mencapai 90.9 juta ton, dengan 79.3 juta ton yang dihasilkan dari perairan laut dan 11.6 juta ton dari perairan daratan (COFI 2018).

Sementara itu, perikanan skala kecil telah menyumbang sekitar 40 persen dari tangkapan ikan dunia (Kalikoski dan Franz 2014). Indonesia menjadi negara kedua setelah Cina yang berkontribusi paling besar pada produksi perikanan dunia pada tahun 2016 (FAO 2018a). Produksi perikanan Indonesia pada tahun 2014 mencapai 20.72 juta ton dan terus tumbuh sebesar 23.19 juta ton dengan nilai produksi $\mathrm{Rp}$ 384.5 trilyun pada tahun 2017. Lebih jauh, produksi perikanan tangkap laut terus meningkat dalam 10 tahun terakhir dari jumlah produksi 4.7 juta ton pada tahun 2007 menjadi sebesar 6.6 juta ton pada tahun 2017 dengan nilai produksi sekitar Rp184.6 trilyun.

Tata Laksana Perikanan yang Bertanggung Jawab. Tata Laksana Perikanan yang Bertanggung Jawab atau Code of Conduct For Responsible Fisheries (CCRF) merupakan salah satu kesepakatan dalam konferensi Committee on Fisheries (COFI) ke-28 FAO di Roma pada tanggal 31 Oktober 1995. Menghasilkan resolusi Nomor: 4/1995 yang secara resmi mengadopsi dokumen Code of Conduct for Responsible Fisheries dan meminta FAO berkolaborasi dengan anggota dan organisasi relevan guna menyusun technical guidelines yang mendukung pelaksanaan dari Code of Conduct for Responsible Fisheries tersebut. Tata laksana ini bersifat global dan menjadi standar internasional dalam praktik perikanan yang bertanggung jawab dimana pengelolaan dan pemanfaatan sumberdaya perikanan secara berkelanjutan harus memperhatikan seluruh aspek yaitu ekologi, teknologi, ekonomi, sosial, lingkungan dan komersial yang relevan terhadap pengelolaan sumberdaya.
Pengelolaan perikanan harus mempromosikan pemeliharaan kualitas, keragaman dan ketersediaan sumber daya perikanan dalam jumlah yang cukup untuk generasi sekarang dan masa depan dalam konteks ketahanan pangan, pengentasan kemiskinan dan pembangunan berkelanjutan. Negara-negara dan semua pihak yang terlibat dalam pengelolaan perikanan harus melalui kebijakan, kerangka hukum dan kelembagaan yang tepat, menerapkan langkah-langkah untuk konservasi jangka panjang dan pemanfaatan sumber daya perikanan secara berkelanjutan (FAO 2011). Sebagai upaya menciptakan pengelolaan berkelanjutan, maka berbagai faktor yang mempengaruhi baik secara internal maupun eksternal perlu diidentifikasi serta status keberlanjutan kebijakan pengelolaan perikanan tangkap tersebut juga perlu diketahui agar dapat dilakukan perbaikan ke arah yang lebih baik (Vatria et al. 2019a, 2019b)

Tujuan CCRF adalah untuk membantu negara-negara dan kelompok negara, membangun atau meningkatkan perikanan dan budidaya perairan mereka, untuk mencapai tujuan akhir mereka yaitu keberlanjutan sistem perikanan global. CCRF ini menjelaskan bagaimana perikanan harus diatur secara bertanggungjawab, dan bagaimana, perikanan beroperasi sesuai dengan peraturan nasional masing-masing negara.

Tujuan CCRF secara rinci antara lain adalah: 1) menetapkan azas sesuai dengan hukum (adat, nasional, dan international) bagi penangkapan ikan dan kegiatan perikanan yang bertanggung jawab; 2) menetapkan azas dan kriteria kebijakan; 3) bersifat sebagai acuan atau himbauan; 4) menjadikan tuntunan dalam setiap menghadapi permasalahan; 5) mempermudah kerjasama teknis dan pembiayaan; 6) meningkatkan kontribusi pangan; 7) meningkatkan upaya perlindungan sumberdaya ikan; 8) menggalakan bisnis 
Perikanan sesuai dengan hukum; dan 9) memajukan penelitian. Terdapat enam topik yang diatur dalam tatalaksana CCRF, antara lain: 1) pengelolaan perikanan, 2) operasi penangkapan, 3) pengembangan akuakultur, 4) Integrasi perikanan ke dalam pengelolaan kawasan pesisir, 5) penanganan pasca panen dan perdagangan, 6) penelitian perikanan.

Langkah-langkah dalam pengelolaan perikanan yang bertanggung jawab (CCRF) harus memperhatikan (FAO 2011): 1) kelebihan kapasitas penangkapan ikan harus dihindari dan ketersediaan stok ikan harus tetap layak secara ekonomi; 2) dalam kegiatan ekonomi, industri perikanan yang beroperasi harus mempromosikan perikanan yang bertanggung jawab; 3) harus memperhitungkan kepentingan nelayan, termasuk yang terlibat dalam subsisten, perikanan skala kecil dan perikanan rakyat; 4) keanekaragaman hayati habitat perairan dan ekosistem harus dijaga kelestariannya dan spesies langka harus dilindungi.

Persediaan stok ikan yang menipis harus di pulihkan secara aktif; 5) dilakukan pemantauan dampak lingkungan yang merugikan terhadap sumber daya dari aktivitas manusia; 6) polusi, limbah, pembuangan, tangkapan dengan peralatan yang hilang atau ditinggalkan, tangkapan spesies non target, spesies ikan dan non-ikan, dan dampak pada spesies terkait atau tergantung diminimalkan, melalui pengembangan dan penggunaan alat tangkap dan teknik selektif, ramah lingkungan dan hemat biaya .

Adopsi CCRF dalam hukum nasional Indonesia diimplementasikan dalam Undangundang No. 31 Tahun 2004 tentang Perikanan dengan perubahannya Undang-Undang Nomor 45 Tahun 2009 dan Undang-undang No. 6 Tahun 1996 tentang perairan Indonesia beserta dengan peraturan pelaksana lainnya berupa peraturan pemerintah dan keputusan menteri.
Implementasi CCRF dituangkan dalam tujuan pembangunan perikanan nasional antara lain: 1) meningkatkan taraf hidup nelayan kecil dan pembudidaya ikan; 2) meningkatkan penerimaan dan devisa negara; 3) mendorong perluasan dan kesempatan kerja; 4) meningkatkan ketersediaan dan konsumsi sumber protein ikan; 5) mengoptimalkan pengelolaan sumberdaya ikan; 6) meningkatkan produktivitas, mutu nilai tambah, dan daya saing; 7) meningkatkan ketersediaan bahan baku untuk industri pengolahan ikan; 8) mencapai pemanfaatan sumber daya ikan, lahan pembudidayaan ikan, dan lingkungan sumber daya ikan secara optimal; dan 9) menjamin kelestarian sumber daya ikan, lahan pembudidayaan ikan, dan tata ruang.

Implementasi FAO SSF Guidelines di Indonesia. FAO SSF Guidelines merupakan pedoman yang telah dikembangkan sebagai pelengkap dari tata laksana untuk perikanan yang bertanggung jawab (CCRF) yang diterbitkan FAO pada tahun 1995. Pedoman tersebut dikembangkan untuk memberikan pedoman yang berkaitan dengan perikanan skala kecil dalam mendukung keseluruhan prinsip-prinsip dan ketentuan-ketentuan dari CCRF. Oleh karena itu, FAO SSF Guidelines dimaksudkan untuk mendukung visibilitas, pengakuan dan peningkatan peran penting perikanan skala kecil yang berkontribusi terhadap upaya-upaya nasional dan global menuju pengentasan kelaparan dan kemiskinan (FAO 2015).

FAO SSF Guidelines mendukung
perikanan yang bertanggungjawab dan
pengembangan sosial ekonomi yang
berkelanjutan bagi kepentingan generasi
sekarang dan yang akan datang, dengan
penekanan pada nelayan skala kecil dan buruh
nelayan dan kegiatan-kegiatan terkait serta
mencakup orang-orang yang rentan dan


termarjinalkan dengan mendorong pendekatan berbasis hak asasi manusia (HAM) (KKP 2014).

FAO SSF Guidelines telah dikembangkan melalui proses partisipatif dan konsultatif, yang melibatkan perwakilanperwakilan masyarakat nelayan skala kecil, organisasi masyarakat sipil, pemerintah, organisasi regional dan pemangku kepentingan lainnya. Konsultan teknis FAO telah meninjau kembali pedoman ini.

Mereka juga turut memperhatikan berbagai prinsip-prinsip dan pertimbanganpertimbangan yang penting, termasuk kesetaraan dan non-diskriminasi, partisipasi dan inklusi, akuntabilitas dan supremasi hukum, serta prinsip bahwa HAM bersifat universal, tak terpisahkan, saling terkait dan saling tergantung. Mereka juga mempertimbangkan pedoman perikanan yang bertanggung jawab (CCRF) nomor 10 yaitu tentang " meningkatkan kontribusi perikanan skala-kecil untuk pengentasan kemiskinan dan ketahanan pangan", serta instrumen sukarela internasional lainnya, seperti pedoman sukarela tentang tata kelola yang bertanggung jawab dari penguasaan lahan, perikanan dan kehutanan dalam konteks ketahanan pangan nasional (pedoman kepemilikan) dan pedoman sukarela untuk mendukung realisasi progresif hak untuk pemenuhan makanan dalam konteks ketahanan pangan (pedoman hak atas pangan), yang berlaku.

Negara dan pemangku kepentingan lainnya didorong untuk juga mengkonsultasikan pedoman-pedoman lainnya tersebut, serta instrumen-instrumen internasional dan regional yang relevan, untuk sepenuhnya mengintegrasikan kewajiban yang berlaku, komitmen sukarela dan bimbingan yang tersedia (FAO 2015).
Pembangunan perikanan tangkap skala kecil berkelanjutan memerlukan dukungan dan pemahaman yang memadai tentang bagaimana nelayan kecil hidup dan mencari nafkah (COFI 2016; FAO 2017). FAO telah mengakui pentingnya memahami mata pencaharian dalam konteks keseluruhan pengentasan kemiskinan dan ketahanan pangan (FAO 2017). Pada tingkat internasional, COFI terus mendorong agar FAO SSF Guidelines dapat diadopsi di berbagai negara dalam pembangunan perikanan skala kecil (COFI 2016).

Tujuan FAO SSF Guidelines, adalah (FAO 2015): 1) meningkatkan kontribusi perikanan skala kecil bagi ketahanan pangan dan gizi masyarakat global serta untuk mendukung realisasi progresif dari hak-hak atas pangan yang layak; 2) berkontribusi pada pembangunan masyarakat nelayan skala kecil yang merata dan pengentasan kemiskinan serta meningkatkan kondisi sosial-ekonomi nelayan dan buruh nelayan dalam tatanan pengelolaan perikanan yang berkelanjutan; 3) mencapai pemanfaatan yang berkelanjutan, pengelolaan yang bijaksana dan bertanggung jawab, serta konservasi sumber daya perikanan yang sesuai dengan tata laksana untuk perikanan yang bertanggung jawab (CCRF) dan instrumen terkait lainnya; 4) mendorong kontribusi perikanan skala kecil pada sebuah masa depan yang berkelanjutan secara ekonomi, sosial, dan lingkungan bagi bumi dan manusia; 5) memberikan pedoman yang dapat dijadikan pertimbangan oleh negara dan para pemangku kepentingan untuk pengembangan dan pelaksanaan kebijakan, strategi, dan kerangka hukum yang ramah lingkungan dan partisipatif untuk peningkatan perikanan skala kecil yang bertanggung jawab dan berkelanjutan; 6) untuk meningkatkan kepedulian masyarakat dan mendorong peningkatan pengetahuan mengenai budaya, peranan, kontribusi, dan potensi perikanan skala kecil, dengan 
mempertimbangkan pengetahuan leluhur dan tradisional, dan berbagai kendala dan peluang yang dihadapinya.

Kongres perikanan skala kecil dunia ke-3 (3WSFC), yang diadakan di Chiang Mai Thailand pada bulan Oktober 2018 mencoba merumuskan rencana aksi dan program pengembangan kapasitas perikanan skala kecil. Kongres tersebut mendukung implementasi FAO SSF melalui pendekatan transdiscipline. Membuka kesempatan bagi para peneliti, praktisi, organisasi masyarakat, dan pembuat kebijakan untuk lebih berkontribusi. Melibatkan berbagai disiplin ilmu dan lintas sektoral agar dapat merumuskan rencana aksi dan program pengembangan kapasitas secara komprehensif (Kerezi et al. 2019).

Kongres tersebut merekomendasikan rencana aksi dalam implementasi FAO SSF Guidelines, antara lain: 1) pemerintah perlu mengakui hak masyarakat atas wilayah penangkapan nelayan skala kecil, yang dapat diakses melalui berbagai media; 2) mengorganisir nelayan di setiap komunitas untuk berbicara dalam satu suara, membangun kapasitas dan mempromosikan pendidikan untuk meningkatkan komunikasi antara mereka dan pemerintah dan berpartisipasi dalam proses pengambilan keputusan; 3) memastikan komunikasi lintas level dan bekerja menuju arah yang lebih baik; 4) mengintegrasikan perikanan laut dan darat untuk memperkuat posisi perikanan skala kecil; 5) memfasilitasi keterlibatan perempuan dalam implementasi FAO SSF Guidelines; 6) mempromosikan transparansi dan partisipasi dalam proses implementasi; 7) mendorong pengumpulan data yang lebih konsisten tentang perikanan skala kecil untuk diintegrasikan dalam proses kebijakan; 8) sosialisasi kebijakan yang lebih baik pada perikanan skala kecil sehingga nelayan menjadi lebih tahu; 9) tim transdisiplin perlu meramalkan partisipasi aktif komunitas nelayan di sepanjang siklus perumusan program/kebijakan.

Dalam konteks jaminan keberlanjutan perikanan skala kecil di Indonesia setidaknya terdapat empat payung hukum yang menjadi dasar untuk meningkatkan kesejahteraan nelayan.

Pertama adalah Undang-Undang Nomor 31 Tahun 2004 tentang Perikanan dan perubahannya Undang-Undang Nomor 45 Tahun 2009 yang mengakomodir kebebasan nelayan kecil untuk tidak memiliki surat izin usaha perikanan (SIUP), surat izin penangkapan ikan (SIPI), dan surat izin kapal pengangkut ikan (SIKPI), tidak dikenakan pungutan perikanan, dan adanya kewajiban pemerintah untuk memberdayakan nelayan kecil dalam bentuk skim kredit, pendidikan, pelatihan, penyuluhan, dan penumbuhkembangan.

Kedua adalah Undang-Undang Nomor 27 Tahun 2007 Tentang Pengelolaan Wilayah Pesisir dan Pulau-Pulau Kecil dan perubahannya Undang-Undang Nomor 1 Tahun 2014 yang mengakomodir pemberian hak kepada masyarakat untuk mengusulkan wilayah penangkapan ikan secara tradisional ke dalam RZWP3K.

Ketiga adalah Undang-Undang Nomor 32 Tahun 2014 Tentang Kelautan yang mengakomodir perlunya perluasan kesempatan kerja dalam industri perikanan untuk meningkatkan kesejahteraan nelayan. Keempat adalah Undang-Undang Nomor 7 Tahun 2016 Tentang Pemberdayaan dan Perlindungan Nelayan, Pembudi Daya Ikan, dan Petambak Garam yang telah mengakomodir segala upaya untuk membantu Nelayan dalam menghadapi permasalahan kesulitan melakukan usaha perikanan.

Kementerian Kelautan dan Perikanan (KKP) sebagai otoritas kompeten bidang 
perikanan setidaknya telah menerbitkan dua peraturan pelaksana Undang-Undang Nomor 7 Tahun 2016.

Pertama adalah Peraturan Menteri Kelautan dan Perikanan Nomor 18 Tahun 2016 Tentang Jaminan Perlindungan Atas Risiko Kepada Nelayan, Pembudi Daya Ikan, dan Petambak Garam yang mengatur pelaksanaan pemberian jaminan perlindungan atas risiko dalam bentuk asuransi.

Kedua adalah Peraturan Menteri Kelautan dan Perikanan Nomor 3 Tahun 2019 Tentang Partisipasi Masyarakat dalam Penyelenggaraan Perlindungan dan Pemberdayaan Nelayan, Pembudi Daya Ikan, dan Petambak Garam yang mengatur upayaupaya yang dapat dilakukan masyarakat untuk berkontribusi dalam perlindungan dan pemberdayaan baik pada tahap perencanaan, pelaksanan, pendanaan dan pembiayaan, serta pengawasan.

Namun demikian, Peraturan Pemerintah tentang pengawasan perencanaan dan pelaksanaan perlindungan dan pemberdayaan tersebut dan Peraturan Presiden tentang pemberian subsidi bagi nelayan kecil belum tersedia, sehingga dirasakan peraturan pelaksana Undang-Undang Nomor 7 Tahun 2016 masih belum maksimal.

Sementara itu, untuk dapat memberikan upaya perlindungan dan pemberdayaan yang terintegrasi, terkoordinir, dan tepat sasaran, Undang-Undang Nomor 7 Tahun 2016 mewajibkan pemerintah pusat dan daerah menyusun rencana perlindungan dan pemberdayaan tersebut di tingkat nasional, provinsi, dan kabupaten/kota. Rencana ini akan menjadi bagian integral dari rencana pembangunan nasional, rencana pembangunan daerah, rencana APBN, dan rencana APBD. Namun demikian, sampai saat ini rencana perlindungan dan pemberdayaan nelayan, pembudi daya ikan, dan petambak garam belum tersedia.

Terkait hal tersebut, maka perlu dilakukan penyempurnaan tata kelola perikanan skala kecil di Indonesia. Mulai dari sinergitas kelembagaan antara pemerintah pusat, provinsi, dan kabupaten/kota. Kemudian singkronisasi Undang-Undang dan peraturan pelaksana di bawahnya baik tingkat pusat maupun daerah. Termasuk yang tidak kalah pentingnya adalah partisipasi masyarakat nelayan didalamnya. Partisipasi masyarakat sangat memengaruhi keberhasilan proyek pembangunan berkelanjutan (Wever et al. 2012).

Titik awal dalam penyempurnaan tata kelola dapat dimulai dengan memeriksa kembali keseluruhan hubungan antara struktur kelembagaan dan proses tata kelola yang telah ada (Shankland 2000). Kemudian melakukan singkronisasi peran (roles), tanggung jawab (responsibilities), hak (rights), dan hubungan (relations) yang telah terjadi antara struktur kelembagaan dan proses tata kelola tersebut.

Peran berguna untuk memahami kembali siapa (organisasi mana) dan sebenarnya melakukan apa (DFID 2001; Allison dan Ellis 2001). Tanggung jawab untuk melihat sejauh mana organisasi bertanggung jawab, apakah cukup memadai tanggung jawab yang diberikan, dan bagaimana tanggung jawab itu ditetapkan dan ditegakkan (DFID 2001; Kollmair dan Gamper 2002). Hak menggambarkan kesadaran organisasi terhadap hak dasar individu atau organisasi (Kollmair dan Gamper 2002). Harus dipastikankan apakah antara hak dan tanggung jawab yang diberikan sudah sepadan dan apakah hak mereka sudah ditegakkan atau dilindungi (Shankland 2000; Vatria 2019).

\section{SIMPULAN}


Perikanan skala kecil sangat berperan penting terhadap pengentasan kemiskinan dan ketahanan pengan dunia khususnya Indonesia. Tata Laksana Perikanan yang Bertanggung Jawab (CCRF) merupakan acuan utama pembangunan perikanan berkelanjutan telah di akomodir dalam hukum Indonesia terutama pada Undang-Undang Nomor 45 Tahun 2009. Dalam tataran kebijakan, Indonesia juga telah mengimplementasikan FAO SSF Guidelines dalam hukum nasional terutama UndangUndang Nomor 7 Tahun 2016 tentang Pemberdayaan dan Perlindungan Nelayan, Pembudi Daya Ikan, dan Petambak Garam yang telah mengakomodir segala upaya untuk membantu Nelayan skala kecil dalam menghadapi permasalahan kesulitan melakukan usaha perikanan.

Namun demikian diperlukan penyempurnaan tata kelola perikanan skala kecil mulai dari sinergitas kelembagaan antara pemerintah pusat, provinsi, dan kabupaten/kota dan singkronisasi Undang-Undang dan peraturan pelaksana di bawahnya baik tingkat pusat maupun daerah, serta partisipasi masyarakat nelayan didalamnya.

\section{DAFTAR PUSTAKA}

Allison EH, Ellis F. 2001. The livelihoods approach and management of small-scale fisheries. Mar. Policy. 25(1) 377-388.

Barnes-Mauthe M, Oleson KLL, Zafindrasilivonona B. 2013. The total economic value of small-scale fisheries with a characterization of post-landing trends: An application in Madagascar with global relevance. Fish. Res. 147 175-185. doi:10.1016/j.fishres.2013.05.011

BPS. Badan Pusat Statistik. 2019a. Kemiskinan dan Ketimpangan (Internet). Tersedia pada

https://www.bps.go.id/subject/23/kemisk inan-dan-
ketimpangan.html\#subjekViewTab1.

Diakses 19 Mei 2019.

BPS. Badan Pusat Statistik. 2019b. Statistik Perikanan [internet]. Tersedia pada https://www.bps.go.id/subject/56/perikan an.html\#subjekViewTab4. Diakses 12 Maret 2019.

COFI. Committee on Fisheries. 2016. Securing Sustainable Small-Scale Fisheries: Towards Implementation of the Voluntary Guidelines for Securing Sustainable Small-Scale Fisheries in the Context of Food Security and Poverty Eradication (SSF Guidelines). Rome (IT).

COFI. Committee on Fisheries. 2018. State of World Fisheries and Aquaculture. Report Prepared for the Thirty-third Session of the Committee on Fisheries. Rome (IT).

DFID. Department for International Development. 2001. Sustainable Livelihoods Guidance Sheets. London (GB): DFID.

FAO. Food and Agriculture Organization. 2011. Code of Conduct for Responsible Fisheries. Rome (IT): FAO.

FAO. Food and Agriculture Organization. 2015. Voluntary Guidelines for Securing Sustainable Small-scale Fisheries in the Context of Food Security and Poverty Eradication. Rome (IT): FAO.

FAO. Food and Agriculture Organization. 2017. Food Security and Livelihoods. Rome (IT): FAO.

FAO. Food and Agriculture Organization. 2018a. FAO Yearbook: Fisheries and Aquaculture Statistics 2016. FAO Statistic. Rome (IT): FAO.

FAO. Food and Agriculture Organization. 2018b. Measuring up to the 2030 Agenda for Sustainable Development. FAO and The SDGs. Rome (IT): FAO.

Garcia SM, Ye Y, Jake R, Charles A. 2018. Rebuilding of marine fisheries. Part 1: Global review. Di dalam: FAO Fisheries and Aquaculture Technical Paper 630/1 p. 273. Rome (IT): FAO. 
Kalikoski DC, Franz N. 2014. Strengthening Organizations and Collective Action in Small-scale Fisheries. Di dalam: FAO Fisheries and Aquaculture Proceedings No. 32 pp. 105-168. Rome (IT): FAO.

Kerezi V, Aguión A, Andrews E, Arias Schreiber M, Beckensteiner J .2019. Supporting the implementation of the SSF Guidelines: Report from the 3rd World Small-Scale Fisheries Congress. Too Big To Ignore Research Report, number $R$ 03/2019. St. John's (CA).

KKP. Kementerian Kelautan dan Perikanan Republik Indonesia. 2014. Petunjuk Sukarela untuk Menjamin Perikanan Skala Kecil yang Berkelanjutan dalam Konteks Ketahanan Pangan dan Pengentasan Kemiskinan. Jakarta (ID): KKP.

KKP. Kementerian Kelautan dan Perikanan Republik Indonesia. 2015. Permen KP nomor 45/PERMEN-KP/2015 tentang Perubahan Atas Peraturan Menteri Kelautan dan Perikanan Nomor 25/PERMEN-KP/2015 Tentang Rencana Strategis Kementerian Kelautan dan Perikanan Tahun 2015-2019. Jakarta (ID): KKP.

Kollmair M, Gamper S. 2002. The Sustainable Livelihood Approach: Input Paper for the Integrated Training Course of NCCR North-South Aeschiried. Zurich (CH): University of Zurich.

Nguyen VM, Lynch AJ, Young N, Cowx IG, Beard TD, Taylor WW, Cooke SJ. 2016. To manage inland fisheries is to manage at the social-ecological watershed scale. J. Environ. Manage. 181(1) 312-325. doi:10.1016/j.jenvman.2016.06.045

Schuhbauer A, Sumaila UR. 2016. Economic viability and small-scale fisheries-A review. Econ. 124 69-75. doi:10.1016/j.ecolecon.2016.01.018

Shankland A. 2000. Analysing Policy for Sustainable Livelihoods. IDS Research Report No.49. Sussex (GB).
Sugiyono. 2013. Metode Penelitian Kuantitatif, Kualitatif dan $R \& D$. Bandung (ID): Alfabeta.

Vatria B. 2019. Evaluasi Pembangunan Perikanan Tangkap Skala Kecil di Kabupaten Kayong Utara Provinsi Kalimantan Barat [Disertasi]. Bogor (ID): Institut Pertanian Bogor.

Vatria B, Wiryawan B, Wiyono ES, Baskoro MS. 2019a. Klasterisasi Karakteristik Perikanan Tangkap Skala Kecil di Kabupaten Kayong Utara. Mar. Fish. 10(1) 95-106.

Vatria B, Wiryawan B, Wiyono ES, Baskoro MS. 2019b. The resilience of small fishermen' $s$ livelihood in Maya Island Indonesia; a case study on purse seine capture fisheries. AACL Bioflux. 12(1) 310-319.

Veiga P, Pita C, Rangel M, Gonçalves JMS, Campos A, Fernandes PG, Sala A, Virgili M, Lucchetti A, Brčić J, Villasante S, Ballesteros MA, Chapela R, Santiago JL, Agnarsson S, Ögmundarson Ó, Erzini K. 2016. The EU landing obligation and European small-scale fisheries: What are the odds for success? Mar. Policy. 6464 71. doi:10.1016/j.marpol.2015.11.008

Westlund L, Zelasney J. 2019. Securing sustainable small-scale fisheries: Sharing good practices from around the world. Di dalam: FAO Fisheries and Aquaculture Technical Paper No. 644 p. 184. Rome (IT): FAO.

Wever L, Glaser M, Gorris P, Ferrol-Schulte D. 2012. Decentralization and participation in integrated coastal management: Policy lessons from Brazil and Indonesia. Ocean Coast. Manag. $66 \quad 63-72$. doi:10.1016/j.ocecoaman.2012.05.001

World Bank. 2018. Poverty and Shared Prosperity 2018: Piecing Together The Poverty Puzzle. Washington (US): The World Bank. doi:10.1596/978-1-46480958-3. 